\title{
Available Phosphorus in Soils Amended with Organic N-Enriched Composts during Periods of Incubation
}

\author{
F. O. Fawole ${ }^{1}$, O. J. Ayodele ${ }^{1} \&$ G. O. Adeoye ${ }^{2}$ \\ ${ }^{1}$ Department of Soil Resources and Environmental Management, Ekiti State University, Ado-Ekiti, Nigeria \\ ${ }^{2}$ Department of Agronomy, University of Ibadan, Ibadan, Nigeria \\ Correspondence: F. O. Fawole, Department of Soil Resources and Environmental Management, Ekiti State \\ University, Ado-Ekiti, Nigeria. E-mail: princesssadefisayo@yahoo.com
}

Received: October 8, 2019 Accepted: September 18, $2020 \quad$ Online Published: July 20, 2021

doi:10.5539/jps.v10n2p20 URL: https://doi.org/10.5539/jps.v10n2p20

\begin{abstract}
Inorganic nitrogen $(\mathrm{N})$ fertilizers, microbial inoculum and biologically-active substances are used to fortify composts which characteristically contain low amounts of $\mathrm{N}$. The potentials of organic wastes from agriculture for $\mathrm{N}$ enrichment of composts were indicated by significant increase in soil $\mathrm{N}$ while there can be fortuitous improvement in the available phosphorus $(\mathrm{P})$ contents on which information about the extent is lacking. In this study, composts: cow dung + sawdust (CDSD) and poultry droppings + sawdust (PDSD) were enriched with meals from bone (BN), blood (BM), hoof (HF) and horn (HN); and neem leaf (NM) and tithonia leaf (TM) to attain 150, 300, 450 and $600 \mathrm{~g} \mathrm{~kg}^{-1} \mathrm{~N}$ and the available $\mathrm{P}$ was monitored at four-week intervals during 16 weeks of incubation in soil. Available $\mathrm{P}$ increased with all $\mathrm{N}$ sources and enrichment rates slightly at week 4 but highly from week 8 and for each source, the enrichment to $600 \mathrm{~g} \mathrm{~kg}^{-1} \mathrm{~N}$ gave the highest values. The composts enriched to 450 and $600 \mathrm{~g} \mathrm{~kg}^{-1} \mathrm{~N}$ gave $15-20$ and $20-29 \mathrm{mg} \mathrm{kg}^{-1}$ available $\mathrm{P}$ in week 12 and 16 respectively. CDSDBM and PDSDHF enriched to $600 \mathrm{~g} \mathrm{~kg}^{-1} \mathrm{~N}$ at week 4 and 8 respectively can be used for short-season crops while PDSDBM and PDSDNM enriched to $600 \mathrm{~g} \mathrm{~kg}^{-1} \mathrm{~N}$ in week 12 and 16 respectively would be suitable for long-season crops. The PDSDNM enriched to $600 \mathrm{~g} \mathrm{~kg}^{-1} \mathrm{~N}$ gave the highest available $\mathrm{P}\left(29.0 \mathrm{mg} \mathrm{kg}^{-1}\right)$ and was followed by PDSDBN and PDSDHF at the same enrichment level, with $28.0 \mathrm{mg} \mathrm{kg}^{-1}$ each. Although the PMSDNM enriched to $600 \mathrm{~g} \mathrm{~kg}^{-1} \mathrm{~N}$ had the highest available $\mathrm{P}$ in week 16 , the enriched composts with values exceeding $20 \mathrm{mg} \mathrm{kg}^{-1}$ also have potentials for the cultivation of long-season vegetables.
\end{abstract}

Keywords: composts, agricultural wastes, enrichment, incubation, available P content

\section{Introduction}

Soils in the humid tropics contain low amounts of organic matter and available nutrients such that their productivity declines over time, especially under continuous cultivation (Zingore, Mafongoya \& Giller, 2003). Crop yields have stagnated or declined due to increased soil degradation from anthropogenic sources, poor access to chemical fertilizers and a coping strategy of intensifying land use which accentuates nutrient 'mining'. Since agriculture will remain a soil-based industry, nutrient depletion must be tackled in order to attain the desired increases in crop productivity. The declining crop yields from continuous use of chemical fertilizers are due to increased soil acidity and nutrient imbalance whereas several studies have indicated the positive effects of organic sources of nutrients on soil productivity (Anikwe, 2000). Thus, farming practices that encourage natural processes (minerals, manures, symbiosis etc) for nutrient supply are now being promoted.

Compost is organic manure produced from the controlled biological decomposition of organic materials that have been sanitized through the generation of heat and stabilized to the point that it is beneficial to plant growth (Donahue, Miller \& Schicichuna, 1990). Composting is used to manage high-volume solid organic wastes in an environment-friendly manner by converting them to useful soil amendments vital to organic farming as a source of organic matter and able to improve the chemical, physical and biological characteristics of soils (Rodale, 2012). All organic materials can be used for composting but the most common are cow dung, poultry droppings and sawdust. Cow dung consists of the fibrous material that passed through the animal's digestive system along other liquid digesta left after the fermentation, absorption and filtration, then acidified and absorbed again. The composition is mainly carbon, hydrogen, oxygen, nitrogen $(\mathrm{N})$, phosphorus $(\mathrm{P})$ and salts, cells sloughed off as the digesta went through the digestive tract, some urea, mucus, as well as cellulose, lignin and hemicelluloses. 
Thus, the resultant faecal matter is rich in minerals (Rodale, 2004) and has been used alone (Kekong, Ayuba \& Ali, 2010) or in combination with other materials in the form of composts (Adeoye, Ojobor \& AdeOluwa, 2004) for soil maintenance. Poultry manure consists of the droppings from birds kept under battery cage and deep litter systems. Often, the droppings alone or mixed with the bedding materials are collected for use as manure. It contains of all the basic nutrients necessary for crops, especially $\mathrm{N}, \mathrm{P}$, potassium $(\mathrm{K})$ and calcium $(\mathrm{Ca})$, in amounts higher than all livestock classes and can be applied directly from the farm to the fields (Prabu, 2009), to be used alone (Kekong, Ayuba \& Ali, 2010) or combined with other materials to produce composts (Eneje \& Ezeakolam, 2009). Sawdust is the solid organic waste, composed of fine particles of wood, generated during the production of sawn wood from timber logs in sawmills and splitting of planks in carpentry workshops. It contains very high carbon in the form of lignin, cellulose and pectin (BWNC, 2013). It is low in useful plant nutrients but can be used as mulch by orchardists, growers of small fruits and nursery men, composts serve as an alternative to clay caste litter fuel and the manufacture of particle boards.

Despite the age-long use and importance of composts, they contain low amounts of $\mathrm{N}$ which make the provision of additional $\mathrm{N}$ input inevitable and the search continues for materials which would be used to improve the contents and enhance the efficiency and quality of composts at low cost. Compost enrichment can involve the use of inorganic fertilizers and mineral ores to develop organo-mineral fertilizers (Zahir et al., 2007), microbial inoculum to hasten lignin decomposition (Manjunatha \& Ravi, 2013) and biologically-active substances (Ahmad et al., 2009)). The potentials of agricultural wastes, as organic $\mathrm{N}$ sources, for raising the $\mathrm{N}$ levels and which would fortuitously increase the P contents of composts (Adegbite \& Olayinka, 2010) should be exploited.

The cattle industry is a source of abattoir wastes- bones, hoofs, blood and horns- which can serve as organic $\mathrm{N}$ sources to enrich composts. The 25 litres of blood obtained from a slaughtered cow can be dried and milled into an inert powder (blood meal) containing $13.25 \% \mathrm{~N}$ which is used to amend finished compost to increase its $\mathrm{N}$ content and balance the $\mathrm{C}: \mathrm{N}$ ratio in compost piles. A slaughtered cow yields $70-90 \mathrm{~kg}$ bones which can be cleaned, dried and burnt or cooked and ground for conversion to bone meal as a slow release organic $\mathrm{P}$ fertilizer that contains $\mathrm{Ca}$ and little N (Scotts, 2012) at N-P-K formula of 4-12-0. The cooked, ground and dehydrated hooves and horns contain $12 \% \mathrm{~N}$ and $2 \% \mathrm{P}$ which make the meals that are 12-2-0 NPK fertilizers.

Plants which produce large amounts of biomass are also needed to address the problems of soil fertility depletion in cropping systems (Vanlauwe \& Giller, 2006) and there is the need to identify species whose leaves contain a large pool of nutrients, especially $\mathrm{N}$ and $\mathrm{P}$ usually at low concentrations in organic inputs and found in the vicinity to reduce labour cost. The neem tree (Azadirachta indica (A. Juss), family Meliaceae, is native to India, Pakistan and Bangladesh but grows in tropical and sub-tropical regions and has naturalized in Nigeria. The leaves contain $2.07 \% \mathrm{~N}, 0.12 \% \mathrm{P}$ and $0.20 \% \mathrm{~K}$ (Rafiu, 2012) and can be used to enrich composts, as mulch and green manure to neutralize soil acidity and provide nutrients and organic matter which improves soil structure and water holding capacity thereby enhancing soil fertility and health (Subbalakshmi et al., 2012; Satish, 2015). Mexican sunflower, wild sunflower [Tithonia diversifolia (Hemsley A. Gray)] is a succulent and soft shrub in the family Asteraceae and native to eastern Mexico and Central America but has a nearly pan-tropical distribution as an introduced weed species in crop farms and waste lands (Taxon, 2012). It accumulates large amounts of nutrients from the soil with the leaves containing $3.2 \% \mathrm{~N}, 0.2 \% \mathrm{P}$ and $3.0 \% \mathrm{~K}$ (Mugwe et al., 2007) which enhance the use as green manure, mulch and fertilizer and for composting.

The cattle abattoir wastes and leaves can be dried, ground into powder (meals) and used as materials to supplement the $\mathrm{N}$ content of composts (Fawole et al., 2019; Rhoades, 2020). All the nutrients taken up by the plants and animals which generate the wastes are contained in manures but the quality is often measured by the $\mathrm{N}$ contents whose eventual release through mineralization processes would provide the explanation for crop responses to manure application. This level of concern has not been expressed for $\mathrm{P}$ which also exists in the organic fraction and undergoes mineralization in a manner similar to N. Rock phosphate (RP) and single superphosphate (SSP) fertilizer are often applied to fortify composts with additional P. (Biswas \& Narayanasamy, 2006; Zahir et al., 2007; Adegbite \& Olayinka, 2010) noted that the enrichment of composts with the agricultural wastes fortuitously increased the total P contents. Therefore, the objectives of this study were to: enrich the composts produced from conventional materials- cow dung, poultry droppings and saw dust with blood, bone, hoof and horn meals, and neem leaf and tithonia leaf meals; and through incubation studies assess its effects on the availability of $\mathrm{P}$ in soils.

\section{Materials and Methods}

The study was carried out on the Teaching and Research Farm, Ekiti State University, Ado-Ekiti, Nigeria (latitude $7^{\circ} 31^{\prime} \mathrm{N}$ and longitude $5^{\circ} 13^{\prime} \mathrm{E}$ ) in South-Western Nigeria. The site is within the rain forest zone and 
experiences a tropical climate with distinct wet and dry seasons which span late March to October with a dry spell in August and November to early March respectively. The mean annual total rainfall is about 1,367 mm while the temperature is almost uniform throughout the year with very little deviation from the mean annual of $27^{\circ} \mathrm{C}$. The agricultural economy is dominated by the cultivation of arable crops (yam, cassava, rice, maize, vegetables) and permanent tree crops (cocoa, kola and oil palm).

Poultry droppings, cattle wastes; blood, horns, hooves, bones and dung and sawdust were collected from designated farms and sawmill. Several branches of neem were cut and the leaves plucked while the young and succulent stalks and leaves of tithonia plants that were not flowering were cut and used. The cattle dung, poultry dung, sawdust, blood, bone, horn, hoof, neem leaf and tithonia leaf samples were air-dried, milled and analyzed for $\mathrm{pH}$ in water at 1:2 ratio, total carbon by chromic acid wet digestion method, total $\mathrm{N}$ by the micro-Kjeldahl method, total $\mathrm{P}, \mathrm{Ca}$, magnesium $(\mathrm{Mg}), \mathrm{K}$ and sodium $(\mathrm{Na})$ by wet digestion using concentrated nitric, perchloric and sulphuric acid mixture at a ratio of 25: 5: 5 respectively. $\mathrm{P}$ in the digests was determined by vanado-molybdate method, $\mathrm{Na}$ and $\mathrm{K}$ were determined by flame photometry while $\mathrm{Ca}$ and $\mathrm{Mg}$ were determined by atomic absorption spectrophotometry (Udo et al., 2010). Cow dung and sawdust (CDSD), poultry droppings and sawdust (PDSD) were mixed at 1:1 ratio (v/v) in separate heaps $1.5 \mathrm{~m}$ wide and $1 \mathrm{~m}$ high, watered and turned fortnightly. At the end of 22 weeks, the organic N sources (blood, bone, hoof, horn, neem and tithonia meals) were mixed with the composts as shown in Table 1 . The enrichment materials were added for the composts to attain $150,300,450$ and $600 \mathrm{~g} \mathrm{~kg}^{-1} \mathrm{~N}$.

The soil used for the incubation study was a slightly acidic (pH 5.8 in $\mathrm{KCl}$ and 6.6 in water) sandy loam with $14.6 \mathrm{~g} \mathrm{~kg}^{-1}$ organic matter content, $0.8 \mathrm{~g} \mathrm{~kg}^{-1}$ total $\mathrm{N}, 13.0 \mathrm{mg} \mathrm{kg}^{-1}$ available $\mathrm{P}$ while the exchangeable bases: $\mathrm{K}$, $\mathrm{Ca}, \mathrm{Mg}$ and $\mathrm{Na}$ were $0.3,7.0,1.8$ and $0.1 \mathrm{cmol} \mathrm{kg}^{-1}$ respectively. Two kilogrammes $(2 \mathrm{~kg})$ of topsoil were weighed into 2.5 litre bowls and each of the enriched composts, at the rate of $30 \mathrm{t} \mathrm{ha}^{-1}$ was thoroughly mixed with the soil, moistened and covered with black polythene sheets and kept in a cool place. Each treatment was in four sets to accommodate the monitoring of available P contents in samples at 4, 8, 12 and 16 weeks of incubation.

Table 1. Treatment combinations and their description

\begin{tabular}{ll}
\hline Treatments & Description \\
\hline CDSD & Cow dung + sawdust \\
CDSDBM & Cow dung + sawdust + blood meal \\
CDSDBN & Cow dung + sawdust + bone meal \\
CDSDHN & Cow dung + sawdust + horn meal \\
CDSDHF & Cow dung + sawdust + hoof meal \\
CDSDTM & Cow dung + sawdust + tithonia leaf meal \\
CDSDNM & Cow dung + sawdust + neem leaf meal \\
PDSD & Poultry droppings + sawdust \\
PDSDBM & Poultry droppings + sawdust + blood meal \\
PDSDBN & Poultry droppings + sawdust + bone meal \\
PDSDHN & Poultry droppings + sawdust + horn meal \\
PDSDHF & Poultry droppings + sawdust + hoof meal \\
PDSDTM & Poultry droppings + sawdust + tithonia leaf meal \\
PDSDNM & Poultry droppings + sawdust + neem leaf meal \\
\hline
\end{tabular}

\section{Results}

Table 2 shows the chemical properties of the composting materials, composts and the enrichment materials. PD, $\mathrm{CD}$ and SD were alkaline ( $\mathrm{pH}=8.0-8.4)$. Poultry dung (PD) gave the highest total $\mathrm{N}, \mathrm{K}$ and $\mathrm{Ca}$ values while the highest total $\mathrm{P}$ was recorded from cow dung (CD). The recorded $\mathrm{Mg}$ contents varied between 6.0 and $6.7 \mathrm{~g} \mathrm{~kg}^{-1}$ in the three composting materials. The results of the analysis of the enrichment materials showed that $\mathrm{BN}, \mathrm{HN}$ and TM were alkaline with $\mathrm{BN}$ having a $\mathrm{pH}$ of 10.5 while both $\mathrm{HN}$ and $\mathrm{TM}$ had 8.2. Other enrichment materials; $\mathrm{BM}, \mathrm{HF}$ and NM were slightly acidic ( $\mathrm{pH}=6.2-6.5)$. The highest $\mathrm{N}\left(98.7 \mathrm{~g} \mathrm{~kg}^{-1}\right)$ was obtained in NM while BN contained the least $\mathrm{N}\left(2.0 \mathrm{~g} \mathrm{~kg}^{-1}\right)$. Highest total $\mathrm{P}$ was recorded in $\mathrm{HN}$ and $\mathrm{BN}$ (25.6 and $24.1 \mathrm{~g} \mathrm{~kg}^{-1}$ respectively) while the other enrichment materials contained $\mathrm{P}$ in the order TM > NM > HF > BM. Hoof (HF) and blood meals (BM) contained the highest $\mathrm{Ca}$ content. The $\mathrm{Mg}$ status was within $5.8-6.6 \mathrm{~g} \mathrm{~kg}^{-1}$ in the enrichment materials while $\mathrm{K}$ and $\mathrm{Na}$ contents varied between 4.1 and $5.1 \mathrm{~g} \mathrm{~kg}^{-1}$ and $0.5-1.1 \mathrm{~g} \mathrm{~kg}^{-1}$ respectively in the materials. The matured composts were alkaline $(\mathrm{CDSD}=8.4$ and $\mathrm{PDSD}=8.2)$; Total $\mathrm{N}, \mathrm{Ca}, \mathrm{Mg}, \mathrm{K}$ and $\mathrm{Na}$ values were higher in 
CDSD while PDSD contained higher total P content.

The available $\mathrm{P}$ contents of soils to which composts enriched with organic $\mathrm{N}$ sources at various levels were added and incubated for 4, 8, 12 and 16 weeks are shown in Figs. 1-4. All the treatments showed increases in available P levels with time of incubation. Available P content of the soils which received CDSD and PDSD controls was 5.4 and $6.1 \mathrm{mg} \mathrm{kg}^{-1}$ in week 4 which increased to 15.0 and $14.5 \mathrm{mg} \mathrm{kg}^{-1}$ in week 16 respectively. Compared to the control, soil available $\mathrm{P}$ was similar for all the composts enriched to $150 \mathrm{~g} \mathrm{~kg}^{-1} \mathrm{~N}$; CDSDBM, CDSDHM, CDSDHF and CDSDNM enriched to $300 \mathrm{~g} \mathrm{~kg}^{-1} \mathrm{~N}$; CDSDBN, CDSDHN and CDSDHF enriched to $450 \mathrm{~g} \mathrm{~kg}^{-1} \mathrm{~N}$ and CDSDBN enriched to $600 \mathrm{~g} \mathrm{~kg}^{-1} \mathrm{~N}$ in week 4.

In week 8, available $\mathrm{P}$ increased at the higher rates of $\mathrm{N}$ enrichment except in soils treated with CDSDBN and CDSDHN enriched to $150 \mathrm{~g} \mathrm{~kg}^{-1} \mathrm{~N}$ and CDSDBN enriched to $300 \mathrm{~g} \mathrm{~kg}^{-1} \mathrm{~N}$ which were not different from the CDSD control. The available P content of the CDSD control was lower than only CDSDNM and CDSDTM enriched to $150 \mathrm{~g} \mathrm{~kg}^{-1} \mathrm{~N}$ but similar to CDSDBN and CDSDHN enriched to $300 \mathrm{~g} \mathrm{~kg}^{-1} \mathrm{~N}$ in week 12 . In week 16 , the application of CDSDNM enriched to all the $\mathrm{N}$ rates gave values that differed from the control whereas CDSDHN and CDSDHF enriched to 150 and $300 \mathrm{~g} \mathrm{~kg}^{-1} \mathrm{~N}$ and CDSDHF enriched to 450 and $600 \mathrm{~g} \mathrm{~kg}^{-1} \mathrm{~N}$ contained values lower than or similar to the control. All the treatments contained available $\mathrm{P}$ similar to the PDSD control in week 4 and higher values in week 8. In week 12, PDSD control gave values similar to the application of composts enriched to attain $150 \mathrm{~g} \mathrm{~kg}^{-1} \mathrm{~N}$ with all the organic sources and PDSDHN and PDSDHF enriched to 300 and $450 \mathrm{~g} \mathrm{~kg}^{-1} \mathrm{~N}$ while the PDSD control gave lower available P in week 16.

The available $\mathrm{P}$ content increased with the level of $\mathrm{N}$ enrichment in each organic material and the longer the incubation period, the higher was the content and the magnitude of increase. For each time of incubation, the application of CDSDHN enriched to $150 \mathrm{~g} \mathrm{~kg}^{-1} \mathrm{~N}$ gave the least available P values while CDSDBM, CDSDBN, CDSDBM and CDSDNM enriched to $600 \mathrm{~g} \mathrm{~kg}^{-1} \mathrm{~N}$ gave the highest values at 4, 8, 12 and 16 weeks of incubation respectively. PDSDBN enriched to $450 \mathrm{~g} \mathrm{~kg}^{-1} \mathrm{~N}$ and PDSDNM, PDSDBM and PDSDNM enriched to $600 \mathrm{~g} \mathrm{~kg}^{-1} \mathrm{~N}$ contained the highest available $\mathrm{P}$ at 4, 8, 12 and 16 weeks respectively. At 16 weeks, the PMSDNM enriched to $600 \mathrm{~g} \mathrm{~kg}^{-1} \mathrm{~N}$ had the highest available $\mathrm{P}$ value of $29.0 \mathrm{mg} \mathrm{kg}^{-1}$ while CDSDHN enriched to attain 150 $\mathrm{g} \mathrm{kg}^{-1} \mathrm{~N}$ contained the least available $\mathrm{P}$ value of $16.2 \mathrm{mg} \mathrm{kg}^{-1}$.

Table 2. Some Chemical Properties of the Compost Materials, Composts and the Organic Wastes used for N Enrichment

\begin{tabular}{|c|c|c|c|c|c|c|c|c|c|c|c|}
\hline Parameters & $\begin{array}{l}\text { Blood } \\
\text { meal }\end{array}$ & $\begin{array}{l}\text { Bone } \\
\text { meal }\end{array}$ & $\begin{array}{l}\text { Hoof } \\
\text { meal }\end{array}$ & $\begin{array}{l}\text { Horn } \\
\text { meal }\end{array}$ & $\begin{array}{l}\text { Tithonia } \\
\text { meal }\end{array}$ & $\begin{array}{l}\text { Neem } \\
\text { meal }\end{array}$ & $\begin{array}{l}\text { Cow } \\
\text { dung }\end{array}$ & $\begin{array}{l}\text { Poultry } \\
\text { droppings }\end{array}$ & $\begin{array}{l}\text { Saw } \\
\text { dust }\end{array}$ & $\begin{array}{l}\text { CDSD } \\
\text { Compost }\end{array}$ & $\begin{array}{l}\text { PDSD } \\
\text { Compost }\end{array}$ \\
\hline $\mathrm{pH}$ & 6.2 & 10.5 & 6.2 & 8.2 & 8.2 & 6.5 & 8.0 & 8.4 & 8.4 & 8.4 & 8.2 \\
\hline Total N $(\mathrm{g} / \mathrm{kg})$ & 78.8 & 2.0 & 58.1 & 44.2 & 82.0 & 98.7 & 53.9 & 79.2 & 0.9 & 64.0 & 42.2 \\
\hline Total C $(\mathrm{g} / \mathrm{kg})$ & 325.6 & 7.8 & 405.4 & 182.6 & 339.1 & 407.8 & 222.9 & 327.2 & 334.3 & 258.0 & 158.0 \\
\hline Total P $(\mathrm{g} / \mathrm{kg})$ & 0.3 & 24.1 & 0.9 & 25.6 & 2.7 & 1.2 & 26.8 & 8.6 & 0.2 & 10.0 & 23.0 \\
\hline $\mathrm{Ca}(\mathrm{g} / \mathrm{kg})$ & 12.2 & 10.9 & 12.1 & 10.0 & 9.7 & 9.2 & 9.5 & 13.1 & 10.4 & 13.0 & 11.5 \\
\hline $\operatorname{Mg}(\mathrm{g} / \mathrm{kg})$ & 6.1 & 5.8 & 6.6 & 6.0 & 6.2 & 5.9 & 6.0 & 6.7 & 6.4 & 6.8 & 6.2 \\
\hline $\mathrm{K}(\mathrm{g} / \mathrm{kg})$ & 4.4 & 4.1 & 5.0 & 4.1 & 5.1 & 4.1 & 4.4 & 5.2 & 4.8 & 6.1 & 5.4 \\
\hline $\mathrm{Na}(\mathrm{g} / \mathrm{kg})$ & 1.1 & 0.8 & 0.7 & 0.7 & 0.5 & 0.5 & 0.8 & 0.8 & 0.5 & 1.3 & 0.4 \\
\hline
\end{tabular}

$\mathrm{CDSD}=$ Cow dung + Sawdust

PDSD $=$ Poultry droppings + Sawdust 


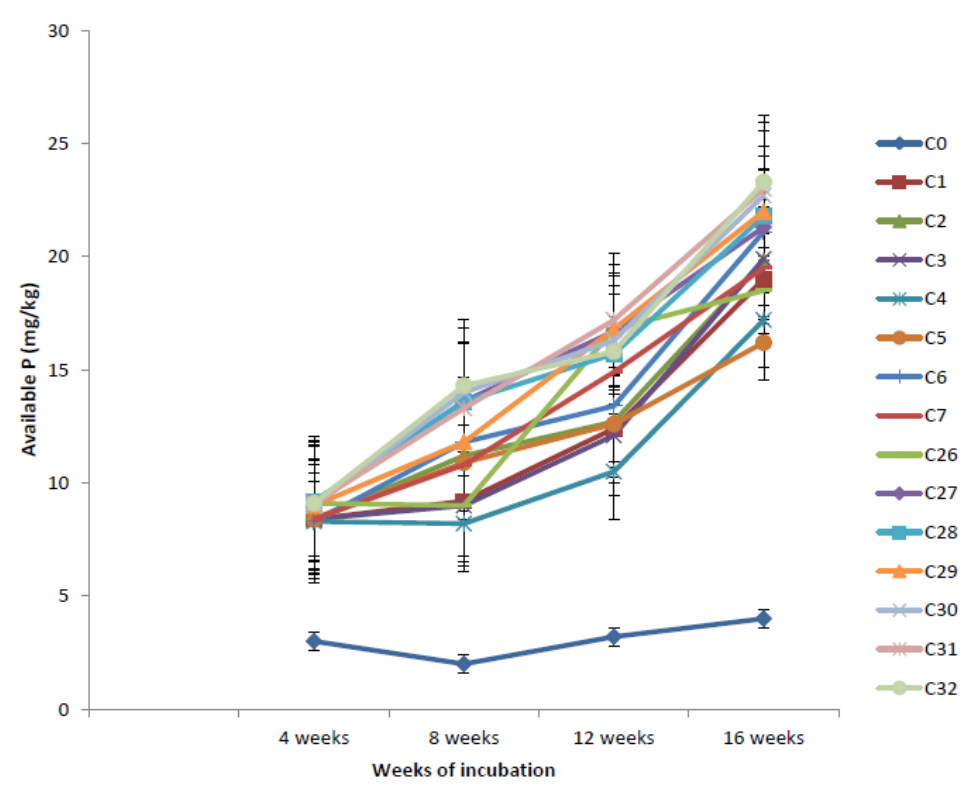

Figure 1. Available P measured monthly during incubation for treatments at $150 \mathrm{~g} \mathrm{~kg}^{-1} \mathrm{~N}$ enrichment level

\section{Legend}

\section{C0 Control}

C1 CDSD

C2 CDSDBM at $150 \mathrm{~g} \mathrm{~kg}^{-1} \mathrm{~N}$

C3 CDSDBM at $150 \mathrm{~g} \mathrm{~kg}^{-1} \mathrm{~N}$

C4 CDSDHM at $150 \mathrm{~g} \mathrm{~kg}^{-1} \mathrm{~N}$

C5 CDSDHN at $150 \mathrm{~g} \mathrm{~kg}^{-1} \mathrm{~N}$

C6 CDSDNM at $150 \mathrm{~g} \mathrm{~kg}^{-1} \mathrm{~N}$

C7 CDSDTM at $150 \mathrm{~g} \mathrm{~kg}^{-1} \mathrm{~N}$

C26 PDSD

C27 PDSDBM at $150 \mathrm{~g} \mathrm{~kg}^{-1} \mathrm{~N}$

C28 PDSDBN at $150 \mathrm{~g} \mathrm{~kg}^{-1} \mathrm{~N}$

C29 PDSDHM at $150 \mathrm{~g} \mathrm{~kg}^{-1} \mathrm{~N}$

C30 PDSDHN at $150 \mathrm{~g} \mathrm{~kg}^{-1} \mathrm{~N}$

C31 PDSDNM at $150 \mathrm{~g} \mathrm{~kg}^{-1} \mathrm{~N}$

C32 PDSDTM at $150 \mathrm{~g} \mathrm{~kg}^{-1} \mathrm{~N}$

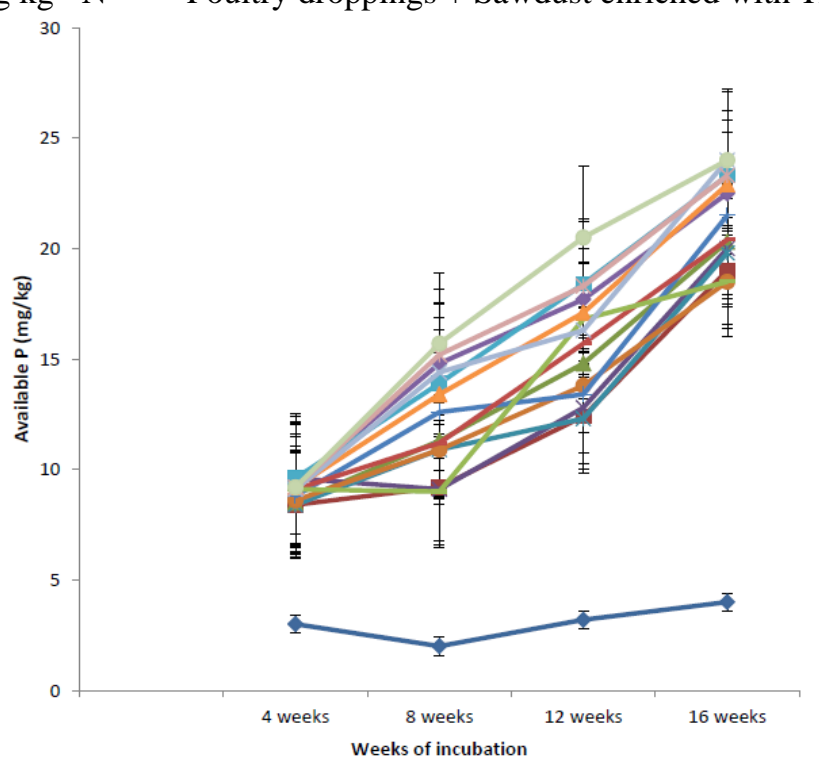

Soil alone

Cow dung + Sawdust

Cow dung + Sawdust enriched with Blood meal at $150 \mathrm{~g} \mathrm{~kg}^{-1} \mathrm{~N}$

Cow dung + Sawdust enriched with Bone meal at $150 \mathrm{~g} \mathrm{~kg}^{-1} \mathrm{~N}$

Cow dung + Sawdust enriched with Hoof meal at $150 \mathrm{~g} \mathrm{~kg}^{-1} \mathrm{~N}$

Cow dung + Sawdust enriched with Horn meal at $150 \mathrm{~g} \mathrm{~kg}^{-1} \mathrm{~N}$

Cow dung + Sawdust enriched with Neem leaf meal at $150 \mathrm{~g} \mathrm{~kg}^{-1} \mathrm{~N}$

Cow dung + Sawdust enriched with Tithonia meal at $150 \mathrm{~g} \mathrm{~kg}^{-1} \mathrm{~N}$

Poultry droppings + Sawdust

Poultry droppings + Sawdust enriched with Blood meal at $150 \mathrm{~g} \mathrm{~kg}^{-1} \mathrm{~N}$

Poultry droppings + Sawdust enriched with Bone meal at $150 \mathrm{~g} \mathrm{~kg}^{-1} \mathrm{~N}$

Poultry droppings + Sawdust enriched with Hoof meal at $150 \mathrm{~g} \mathrm{~kg}^{-1} \mathrm{~N}$

Poultry droppings + Sawdust enriched with Horn meal at $150 \mathrm{~g} \mathrm{~kg}^{-1} \mathrm{~N}$

Poultry droppings + Sawdust enriched with Neem leaf meal at $150 \mathrm{~g} \mathrm{~kg}^{-1} \mathrm{~N}$

Poultry droppings + Sawdust enriched with Tithonia meal at $150 \mathrm{~g} \mathrm{~kg}^{-1} \mathrm{~N}$.

Figure 2. Available P measured monthly during incubation for treatments at $300 \mathrm{~g} \mathrm{~kg}^{-1} \mathrm{~N}$ enrichment level 


\section{Legend}

C0 Control

C1 CDSD

C8 CDSDBM at $300 \mathrm{~g} \mathrm{~kg}^{-1} \mathrm{~N}$

C9 CDSDBN at $300 \mathrm{~g} \mathrm{~kg}^{-1} \mathrm{~N}$

C10 CDSDHM at $300 \mathrm{~g} \mathrm{~kg}^{-1} \mathrm{~N}$

C11 CDSDHN at $300 \mathrm{~g} \mathrm{~kg}^{-1} \mathrm{~N}$

C12 CDSDNM at $300 \mathrm{~g} \mathrm{~kg}^{-1} \mathrm{~N}$

C13 CDSDTM at $300 \mathrm{~g} \mathrm{~kg}^{-1} \mathrm{~N}$

C26 PDSD

C33 PDSDBM at $300 \mathrm{~g} \mathrm{~kg}^{-1} \mathrm{~N}$

C34 PDSDBN at $300 \mathrm{~g} \mathrm{~kg}^{-1} \mathrm{~N}$

C35 PDSDHM at $300 \mathrm{~g} \mathrm{~kg}^{-1} \mathrm{~N}$

C36 PDSDHN at $300 \mathrm{~g} \mathrm{~kg}^{-1} \mathrm{~N}$

C37 PDSDNM at $300 \mathrm{~g} \mathrm{~kg}^{-1} \mathrm{~N}$

C38 PDSDTM at $300 \mathrm{~g} \mathrm{~kg}^{-1} \mathrm{~N}$
Soil alone

Cow dung + Sawdust

Cow dung + Sawdust enriched with Blood meal at $300 \mathrm{~g} \mathrm{~kg}^{-1} \mathrm{~N}$

Cow dung + Sawdust enriched with Bone meal at $300 \mathrm{~g} \mathrm{~kg}^{-1} \mathrm{~N}$

Cow dung + Sawdust enriched with Hoof meal at $300 \mathrm{~g} \mathrm{~kg}^{-1} \mathrm{~N}$

Cow dung + Sawdust enriched with Horn meal at $300 \mathrm{~g} \mathrm{~kg}^{-1} \mathrm{~N}$

Cow dung + Sawdust enriched with Neem leaf meal at $300 \mathrm{~g} \mathrm{~kg}^{-1} \mathrm{~N}$

Cow dung + Sawdust enriched with Tithonia meal at $300 \mathrm{~g} \mathrm{~kg}^{-1} \mathrm{~N}$

Poultry droppings + Sawdust

Poultry droppings + Sawdust enriched with Blood meal at $300 \mathrm{~g} \mathrm{~kg}^{-1} \mathrm{~N}$

Poultry droppings + Sawdust enriched with Bone meal at $300 \mathrm{~g} \mathrm{~kg}^{-1} \mathrm{~N}$

Poultry droppings + Sawdust enriched with Hoof meal at $300 \mathrm{~g} \mathrm{~kg}^{-1} \mathrm{~N}$

Poultry droppings + Sawdust enriched with Horn meal at $300 \mathrm{~g} \mathrm{~kg}^{-1} \mathrm{~N}$

Poultry droppings + Sawdust enriched with Neem leaf meal at $300 \mathrm{~g} \mathrm{~kg}^{-1} \mathrm{~N}$

Poultry droppings + Sawdust enriched with Tithonia meal at $300 \mathrm{~g} \mathrm{~kg}^{-1} \mathrm{~N}$.

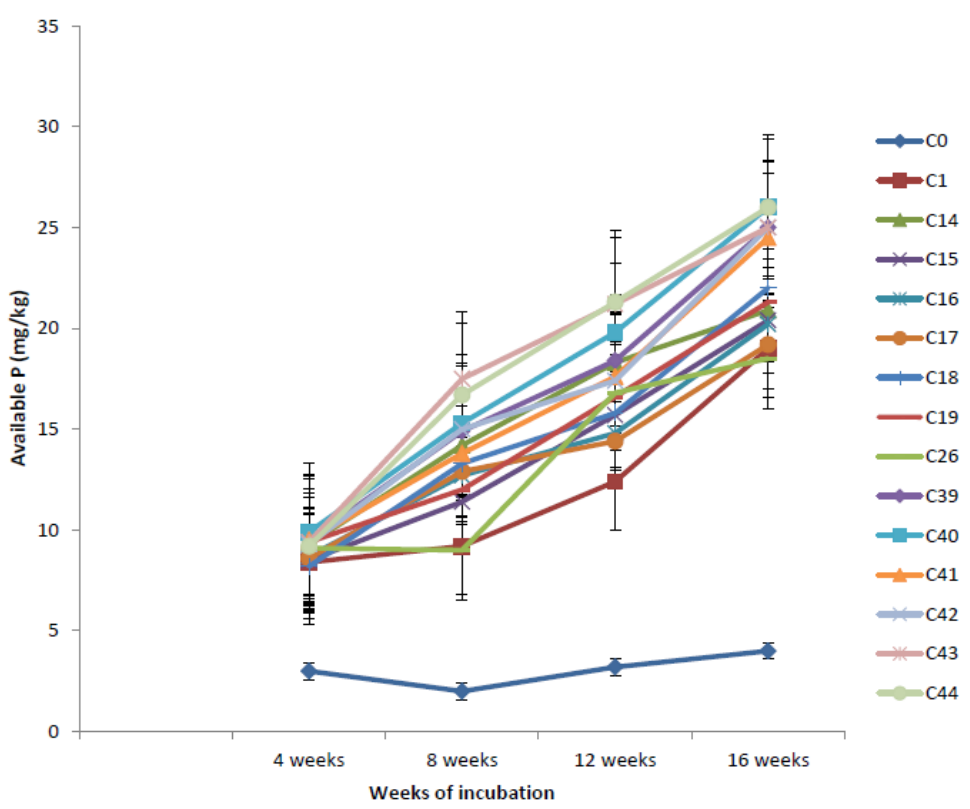

Figure 3. Available $\mathrm{P}$ measured monthly during incubation for treatments at $450 \mathrm{~g} \mathrm{~kg}^{-1} \mathrm{~N}$ enrichment level

\section{Legend}

C0 Control

C1 CDSD

C14 CDSDBM at $450 \mathrm{~g} \mathrm{~kg}^{-1} \mathrm{~N}$

C15 CDSDBN at $450 \mathrm{~g} \mathrm{~kg}^{-1} \mathrm{~N}$

C16 CDSDHM at $450 \mathrm{~g} \mathrm{~kg}^{-1} \mathrm{~N}$

C17 CDSDHN at $450 \mathrm{~g} \mathrm{~kg}^{-1} \mathrm{~N}$

C18 CDSDNM at $450 \mathrm{~g} \mathrm{~kg}^{-1} \mathrm{~N}$

C19 CDSDTM at $450 \mathrm{~g} \mathrm{~kg}^{-1} \mathrm{~N}$

C26 PDSD

C39 PDSDBM at $450 \mathrm{~g} \mathrm{~kg}^{-1} \mathrm{~N}$

C40 PDSDBN at $450 \mathrm{~g} \mathrm{~kg}^{-1} \mathrm{~N}$

C41 PDSDHM at $450 \mathrm{~g} \mathrm{~kg}^{-1} \mathrm{~N}$

C42 PDSDHN at $450 \mathrm{~g} \mathrm{~kg}^{-1} \mathrm{~N}$

C43 PDSDNM at $450 \mathrm{~g} \mathrm{~kg}^{-1} \mathrm{~N}$

C44 PDSDTM at $450 \mathrm{~g} \mathrm{~kg}^{-1} \mathrm{~N}$
Soil alone

Cow dung + Sawdust

Cow dung + Sawdust enriched with Blood meal at $450 \mathrm{~g} \mathrm{~kg}^{-1} \mathrm{~N}$

Cow dung + Sawdust enriched with Bone meal at $450 \mathrm{~g} \mathrm{~kg}^{-1} \mathrm{~N}$

Cow dung + Sawdust enriched with Hoof meal at $450 \mathrm{~g} \mathrm{~kg}^{-1} \mathrm{~N}$

Cow dung + Sawdust enriched with Horn meal at $450 \mathrm{~g} \mathrm{~kg}^{-1} \mathrm{~N}$

Cow dung + Sawdust enriched with Neem leaf meal at $450 \mathrm{~g} \mathrm{~kg}^{-1} \mathrm{~N}$

Cow dung + Sawdust enriched with Tithonia meal at $450 \mathrm{~g} \mathrm{~kg}^{-1} \mathrm{~N}$

Poultry droppings + Sawdust

Poultry droppings + Sawdust enriched with Blood meal at $450 \mathrm{~g} \mathrm{~kg}^{-1} \mathrm{~N}$

Poultry droppings + Sawdust enriched with Bone meal at $450 \mathrm{~g} \mathrm{~kg}^{-1} \mathrm{~N}$

Poultry droppings + Sawdust enriched with Hoof meal at $450 \mathrm{~g} \mathrm{~kg}^{-1} \mathrm{~N}$

Poultry droppings + Sawdust enriched with Horn meal at $450 \mathrm{~g} \mathrm{~kg}^{-1} \mathrm{~N}$

Poultry droppings + Sawdust enriched with Neem leaf meal at $450 \mathrm{~g} \mathrm{~kg}^{-1} \mathrm{~N}$

Poultry droppings + Sawdust enriched with Tithonia meal at $450 \mathrm{~g} \mathrm{~kg}^{-1} \mathrm{~N}$ 


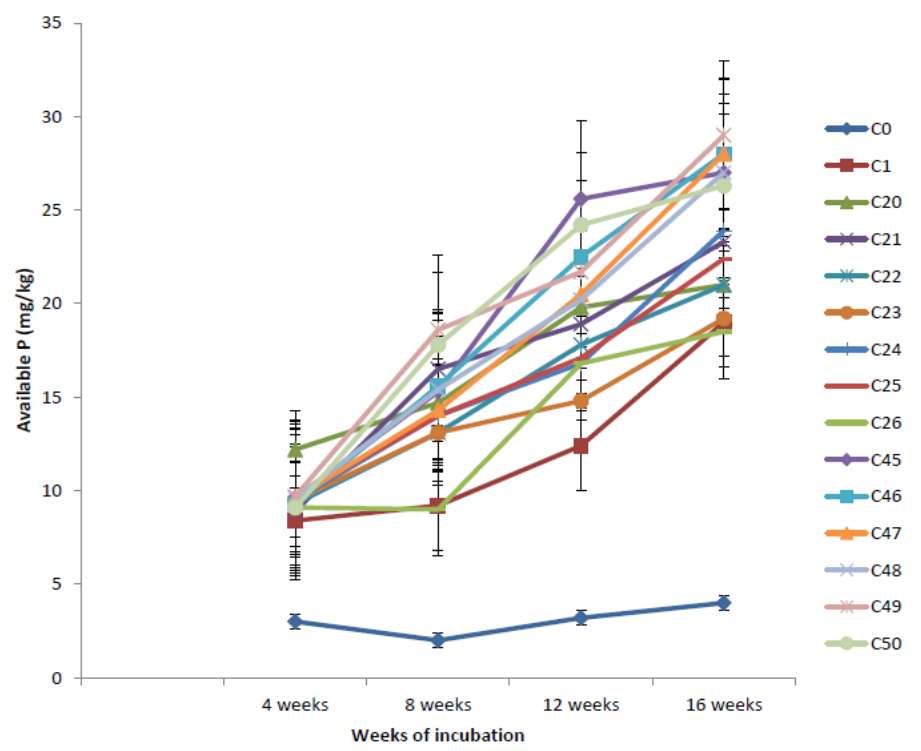

Figure 4. Available $\mathrm{P}$ measured monthly during incubation for treatments at $600 \mathrm{~g} \mathrm{~kg}^{-1} \mathrm{~N}$ enrichment level

\section{Legend}

C0 Control

C1 CDSD

C20 CDSDBM at $600 \mathrm{~g} \mathrm{~kg}^{-1} \mathrm{~N}$

C21 CDSDBN at $600 \mathrm{~g} \mathrm{~kg}^{-1} \mathrm{~N}$

C22 CDSDHM at $600 \mathrm{~g} \mathrm{~kg}^{-1} \mathrm{~N}$

C23 CDSDHN at $600 \mathrm{~g} \mathrm{~kg}^{-1} \mathrm{~N}$

C24 CDSDNM at $600 \mathrm{~g} \mathrm{~kg}^{-1} \mathrm{~N}$

C25 CDSDTM at $600 \mathrm{~g} \mathrm{~kg}^{-1} \mathrm{~N}$

C26 PDSD

C45 PDSDBM at $600 \mathrm{~g} \mathrm{~kg}^{-1} \mathrm{~N}$

C46 PDSDBN at $600 \mathrm{~g} \mathrm{~kg}^{-1} \mathrm{~N}$

C47 PDSDHM at $600 \mathrm{~g} \mathrm{~kg}^{-1} \mathrm{~N}$

C48 PDSDHN at $600 \mathrm{~g} \mathrm{~kg}^{-1} \mathrm{~N}$

C49 PDSDNM at $600 \mathrm{~g} \mathrm{~kg}^{-1} \mathrm{~N}$

C50 PDSDTM at $600 \mathrm{~g} \mathrm{~kg}^{-1} \mathrm{~N}$
Soil alone

Cow dung + Sawdust

Cow dung + Sawdust enriched with Blood meal at $600 \mathrm{~g} \mathrm{~kg}^{-1} \mathrm{~N}$

Cow dung + Sawdust enriched with Bone meal at $600 \mathrm{~g} \mathrm{~kg}^{-1} \mathrm{~N}$

Cow dung + Sawdust enriched with Hoof meal at $600 \mathrm{~g} \mathrm{~kg}^{-1} \mathrm{~N}$

Cow dung + Sawdust enriched with Horn meal at $600 \mathrm{~g} \mathrm{~kg}^{-1} \mathrm{~N}$

Cow dung + Sawdust enriched with Neem leaf meal at $600 \mathrm{~g} \mathrm{~kg}^{-1} \mathrm{~N}$

Cow dung + Sawdust enriched with Tithonia meal at $600 \mathrm{~g} \mathrm{~kg}^{-1} \mathrm{~N}$

Poultry droppings + Sawdust

Poultry droppings + Sawdust enriched with Blood meal at $600 \mathrm{~g} \mathrm{~kg}^{-1} \mathrm{~N}$

Poultry droppings + Sawdust enriched with Bone meal at $600 \mathrm{~g} \mathrm{~kg}^{-1} \mathrm{~N}$

Poultry droppings + Sawdust enriched with Hoof meal at $600 \mathrm{~g} \mathrm{~kg}^{-1} \mathrm{~N}$

Poultry droppings + Sawdust enriched with Horn meal at $600 \mathrm{~g} \mathrm{~kg}^{-1} \mathrm{~N}$

Poultry droppings + Sawdust enriched with Neem leaf meal at $600 \mathrm{~g} \mathrm{~kg}^{-1} \mathrm{~N}$

Poultry droppings + Sawdust enriched with Tithonia meal at $600 \mathrm{~g} \mathrm{~kg}^{-1} \mathrm{~N}$

\section{Discussion}

The replenishment of nutrients continuously removed by crops and the reversal of the usually negative nutrient budgets of soils in order to optimize productivity with chemical fertilizers has been bedevilled by high prices and lack of access due to product scarcity, especially in Nigeria, making the use uneconomical to subsistence farmers (Liverpool-Tasie et al., 2010). The soil application of the wastes generated in animal industries is an environment-friendly means of disposal even as the availability of several organic materials has favoured composting which made composts popular as alternative sources of nutrients in crop production systems (Adeleye \& Ayeni, 2010). Thus, the preparation of composts from cheap organic materials and the use for crop production are strengthened by the ability to maintain soil fertility and dispose livestock industry wastes which would otherwise constitute environmental pollution threats.

In this study, the composts prepared as cow dung + sawdust (CDSD) and poultry droppings + sawdust (PDSD) had become dark brown/black at 22 weeks and were slightly alkaline as an indication of maturity and readiness for use (Muller-Samann \& Kotschi, 1994). The $\mathrm{pH}$ values of the composts were not different from those of the composting materials. This is probably because $\mathrm{Ca}, \mathrm{Mg}$ and $\mathrm{K}$, mainly associated with acidic or alkaline conditions, do not have organic phases despite their roles in various metabolic processes and would not be substantially affected by the microbial breakdown of the organic compounds in plant matter and animal wastes. The total P content of the CDSD was low compared to the cow dung which could be attributed to dilution effect of the sawdust. $\mathrm{N}$ and $\mathrm{P}$ are utilized for the rapid growth and multiplication of the microbial populations involved in organic matter decomposition but the processes involved would hardly engender such substantial losses of P. 
The total P in PDSD was higher than in the poultry droppings. The autochthonous microbial population which ties up $\mathrm{P}$ in the tissues during decomposition of the organic materials is replaced by facultative bacteria as the compost matures (Brady \& Weil, 2004) such that the P is not lost and so would remain in the compost.

The increase in available soil $\mathrm{P}$ content across the treatments throughout the incubation period, even where only the CDSD and PDSD controls were applied, indicates mineralization in the composts but which was little at week 4 and substantial as from week 8 of incubation. Since incubation involved keeping the soil-compost mixtures moist, the microbes present in the soils were active in decomposition of the organic compounds resulting in $\mathrm{P}$ mineralization. There were different peaks of available $\mathrm{P}$ for the enriched composts indicating that the nutrient content and availability vary widely among compost types and are dependent on compost composition and compost maturity (Harrison \& Henry, 1994). However, the steady increase of available P obtained in most of the enriched composts, especially those based on CDSD, could be attributed to the addition of $\mathrm{N}$ through the organic $\mathrm{N}$ sources used to enrich the composts (Adegbite \& Olayinka, 2010).

The patterns of $\mathrm{P}$ availability over the periods of incubation indicate that CDSDBM enriched to $600 \mathrm{~g} \mathrm{~kg}^{-1} \mathrm{~N}$ with the highest available $\mathrm{P}$ at 4 weeks into incubation and PMSDNM enriched to $600 \mathrm{~g} \mathrm{~kg}^{-1} \mathrm{~N}$ which gave the highest $P$ value at 8 weeks into incubation would be suitable for the production of short-season crops that are ready for harvesting between 4 to 8 weeks after planting such as leaf vegetables: leaf amaranth (Amaranthus spp), jute mallow (Corchorus olitorius), Celosia argentea, water leaf (Talinum fruticosum) etc. The PMSDBM enriched to $600 \mathrm{~g} \mathrm{~kg}^{-1} \mathrm{~N}$ which had the highest available $\mathrm{P}$ at 12 weeks and PMSDNM at $600 \mathrm{~g} \mathrm{~kg}^{-1} \mathrm{~N}$ with the highest available $\mathrm{P}$ at 16 weeks incubation would be recommended for long-season crops, especially leaf and fruit vegetables such as okra, tomato, sweet corn, eggplant, egusi (Citrullus lanatus), worowo (Senecio biafrae), fluted pumpkin (Telfairia occidentalis) etc.

\section{Summary and Conclusion}

Some organic materials were identified as sources for compost $\mathrm{N}$-enrichment. The fortuitous increase in available $\mathrm{P}$ was studied in soils to which mature composts enriched to $150,300,450$, and $600 \mathrm{~g} \mathrm{~kg}^{-1} \mathrm{~N}$ equivalent with cattle abattoir wastes (blood, bone, horn, hoof meals), neem leaf and tithonia leaf meals were added and incubated for 16 weeks. The available $\mathrm{P}$ contents increased to the highest values in all the organic $\mathrm{N}$ sources enriched to $600 \mathrm{~g} \mathrm{~kg}^{-1} \mathrm{~N}$ such that CDSDBM and PMSDNM with the highest available P in week 4 and 8 respectively would be suitable for short-season crops while PMSDBM and PMSDNM had the highest available $\mathrm{P}$ in week 12 and 16 respectively and would be recommended for long-season crops, especially leaf and fruit vegetables.

\section{References}

Adegbite, E. A., \& Olayinka, A. (2010). Effect of organic amendments and nitrogen on microbial activity, nitrogen and phosphorus mineralization in an Alfisol. Nigerian Journal of Soil Science, 20, 87-91.

Adeleye, E. O., \& Ayeni, L. S. (2010). Enhancing soil nutrient status and maize yield through organic wastes on an Alfisol in Southwest Nigeria. Nigerian Journal of Soil Science, 20(1), 79-85.

Adeoye, G. O., Ojobor, S. A., \& AdeOluwa, O. O. (2004). Evaluation of potential of co-compost of rice waste, cow dung and poultry manure for production of rice. In Proceedings of the $29^{\text {th }}$ Annual Conference of the Soil Science Society of Nigeria held December 6-10, 2004 at University of Agriculture, Abeokuta, Nigeria. p. 213-218.

Ahmad, R., Khalid, A., Arshad, M., Zahir, Z. A., \& Mahmood, T. (2009). Effect of compost enriched with N and L-tryptophan on soil and maize. Agronomy for Sustainable Development, 28, 299-305. https://doi.org/10.1051/agro:2007058

Anikwe, M. A. N. (2000). Amelioration of a heavy clay loam with rice husk dust and its effect on soil physical properties and maize yield. Bioresource Technology, 16, 102-103. https://doi.org/10.1016/S0960-8524(00)00007-9

Biswas, D. R., \& Narayanasamy, G. (2006). Rock phosphate enriched compost: an approach to improve low-grade Indian rock phosphate. Bioresource Technology, 97, 2243-2251. https://doi.org/10.1016/j.biortech.2006.02.004

Brady, N. C., \& Weil, R. R. (2004). Elements of the Nature and Properties of Soils (2nd ed). Pearson Education Inc., Prentice Hall, Upper Saddle River, New Jersey. pp. 606.

BWNC. (2013). WNC Vegetables and Small Fruits News. Retrieved from http://wncveggies.blogspot.com/2009/02/compost-manure-and sawdust.html 
Donahue, R. L., Miller, R. W., \& Schicichuna, J. C. (1990). Soils: An Introduction to Soils and Plant Growth. Prentice-Hall of India private Ltd., New Delhi. p. 344-351.

Eneje, R. C., \& Ezeakolam, C. S. (2009). Synergistic effect of poultry manure and sawdust on changes in soil structural indices of a sandy-clay loam Ultisols. Nigerian Journal of Soil Science, 19(2), 77-85.

Fawole, F. O., Ayodele, O. J., \& Adeoye, G. O. (2019). Soil Nitrogen Contents as affected by Composts Enriched with Organic Nitrogen Sources. Journal of Experimental Agriculture International, 34(3), 1-11. https://doi.org/10.9734/jeai/2019/v34i330177

Harrison, R. B., \& Henry, C. L. (1994). Judging compost. Grounds Maintenance, 29(3), 10-14.

Kekong, M. A., Ayuba, S. A., \& Ali, A. (2010). Effects of cow dung and poultry droppings on soil chemical properties and yield of garden egg (Solanum spp.) in the sub-humid guinea savanna and rainforest belts of Nigeria. Nigerian Journal of Soil Science, 20(1), 97-104.

Liverpool-Tasie, S., Olaniyan, B., Salau, S., \& Sackey, J. A. (2010). Review of Fertilizer Policy Issues in Nigeria. Nigeria Strategy Support Programme Working Paper. International Food Policy Research Institute, Abuja. p. $1-12$.

Manjunatha, C. K., \& Ravi, M. V. (2013). Evaluation of quality and nutrient status of enriched compost. IOSR Journal of Agriculture and Veterinary Science, 6, 19-23. https://doi.org/10.9790/2380-0621923

Mugwe, J., Mugendi, D., Kungu, J., \& Mucheru-Muna, M. (2007). Effect of plant biomass, manure and inorganic fertilizers on maize yield in the Central Highlands of Kenya. African Crop Science Journal, 15(3), 111-126. https://doi.org/10.4314/acsj.v15i3.54424

Muller-Samann, K. M., \& Kotschi, J. (1994). Sustaining Growth: Soil Fertility Management in the Tropical Smallholdings. (CTA; GTZ.Transl.: Christine Ernsting and Simon Chater). Weikersheim: Margraf. p. 347-379.

Prabu, M. J. (2009). Benefits from Poultry Manure. The Hindu. Retrieved from http://www.thehindu.com/sci-tech/agriculture/article37016.ece

Rafiu, S. (2012). The Potential of Azadirachta indicaLeaf Biomass as a Nutrient Source for Maize Cultivation in Tolon/Kumbungu District of Northern Ghana. Unpublished Master's Thesis- Kwame Nkrumah University of Science and Technology, Kumasi, Ghana.

Rhoades, H. (2020). Using Blood meal to Improve your Garden Soils. Retrieved from http://www.gardeningknowhow.com.

Rodale, J. I. (2004). Farming and Gardening with Composts. Journey to Forever Living. Retrieved from http://org/farm_library/paydirt/paydirt_2d.html

Rodale, J. I. (2012). Composting and Plant Nutrition. Retrieved from http//:www.ibiblio.org/rge/course/compost.html

Satish, L. (2015). BioFuel Activities are picking up Fast. Good Days Again for Jatropha, Pongamia, Mahua, Neem etc and Non-Edible Oils. Retrieved from http//:www.svlele.com/neem.html

Scotts, C. A. (2012). Bone Meal and Blood Meal Enrich Soil Naturally in Organic Gardens. Retrieved from http://www.mnn.com/your-home/organic-farming-gardening/sponsor/bone-meal-and-blood-meal-enrich-soi 1-naturally-in-organic

Subbalakshmi L., Muthukrishnan, P., \& Jeyaraman, S. (2012). Neem products and their agricultural applications. Biopest Journal, 5(Supplementary), 72-76.

Taxon. (2012). Tithonia diversifolia (Hemsl.) A. Gray. Germplasm Resources Information Network. United States Department of Agriculture. Retrieved from http://www.ars-grin.gov/cgi-bin/npgs/html/taxon.pl?36733

Udo, E. J., Ibia, T. O., Ogunwale, J. A., Ano, A. O., \& Esu, I. E. (2010). Manual of Soil, Plant and Water Analysis. Sibon Books Ltd, Lagos. p. 183.

Vanlauwe, B., \& Giller, K. (2006). Popular myths around soil fertility management in sub-Saharan Africa. Agriculture Ecosystem and Environment, 116(1-2), 34-46. https://doi.org/10.1016/j.agee.2006.03.016

Zahir, Z. A., Afzal, A., Ajmal, M., Naveed, M., Asghar, H. N., \& Arshad, M. (2007). Nitrogen enrichment of composted organic wastes for improving growth, yield and Nitrogen uptake of wheat. Journal of Soil and Environment, 26, 15-21. 
Zingore, S. P., Mafongoya, P. M., \& Giller, K. F. (2003). Nitrogen mineralization and maize yield following application of tree pruning to a sandy soil in Zimbabwe. Agroforestry Systems, 57, 199-211.

https://doi.org/10.1023/A:1024887225450

\section{Copyrights}

Copyright for this article is retained by the author(s), with first publication rights granted to the journal.

This is an open-access article distributed under the terms and conditions of the Creative Commons Attribution license (http://creativecommons.org/licenses/by/4.0/). 